\title{
Factors Affecting EMI Attitudes of Engineering and Nursing Students
}

\author{
Jeffrey Dawala Wilang \\ School of Foreign Languages, Institute of Social Technology, Suranaree University of Technology, Nakhon Ratchasima, \\ Thailand
}

Supasinee Nupong

School of Business English, Faculty of Humanities and Social Sciences, Nakhon Ratchasima Rajabhat University, Nakhon Ratchasima, Thailand

\begin{abstract}
The internationalization of higher education has led to the increasing number of English as a Medium of Instruction (EMI) programs in contexts where English is not the first language nor the medium of communication, including Thailand. The introduction of EMI programs, however, is not without challenges. Therefore, a survey questionnaire was used to investigate the attitudes of engineering and nursing students toward EMI. Differences of attitudes based on the program of study, gender, nationality, year level, number of years studying English, the language of instruction in high school, Common European Framework of Reference for Languages (CEFR) level, and perceived proficiencies in speaking, reading, writing, and listening were explored. In addition, factors affecting the students' EMI attitudes were known using exploratory factor analysis. Findings have shown significant differences in various aspects of EMI based on the program of study, CEFR level, and perceived proficiencies of the four macro language skills. Also, eight factors were elicited, including difficulties of the English language, availability of resources and opportunities, personal goals in life, limitations of time when studying content courses in English, providing activities to improve English language proficiency, enhancement of career goals, supports needed, and motivation and intercultural ability. Finally, implications were outlined to support the implementation of EMI, dubbed as an "unstoppable train", in similar contexts like Thailand.
\end{abstract}

Index Terms — attitudes, English as a medium of instruction, engineering, nursing

\section{INTRODUCTION}

Driven by the internationalization of higher education worldwide, a growing global phenomenon of English as a medium of instruction (EMI) has been widely implemented in non-English speaking countries (Byun, Chu, Kim, Park, Kim, \& Jung, 2011; Huang, 2013; Dearden, 2015; Fenton-Smith, Humphries \& Walkinshaw, 2017; Macaro, Curle, Pun, An, \& Dearden, 2018). As a result, EMI has become a means of enhancing students' English language ability and increasing the competitiveness of higher education to meet the growing local, national, and international demands for English skills. In addition, employees need to have both English competence and subject knowledge in the global labor market. With various perceived benefits of EMI in a higher education context, many universities throughout Asia, including Thailand, are increasing the number of courses or programs they are offering students through English (Doungphummes \& Chandransu, 2016; Luanganggoon, 2020).

Though EMI is widely implemented, several challenges encountered were reported. One of the most significant challenges in EMI courses and programs is English language proficiency (Macaro, Curle, Pun, An, \& Dearden, 2018; Chen, Han, \& Wright, 2020). Students encounter linguistic challenges when adapting to an English-only environment due to their inadequate linguistic skills (Galloway \& Ruegg, 2020). Inadequate language proficiency among learners has been found to impact learners in different ways, such as difficulty in understanding lectures, difficulty in taking notes, problems communicating disciplinary content, difficulty in understanding academic texts as well as requiring more time to complete a task (Galloway, Kriukow, \& Numajiri, 2017; Hellekjær, 2010; Andrade, 2006; Kırkgöz, 2005).

Students' attitudes towards EMI have also been identified as a challenge in the higher education context. Perceptions of low language proficiency could lead to negative attitudes towards EMI courses and programs as well as towards the English language itself, which is related to lower levels of student motivation (Lei \& Hu, 2014; Studer \& Konstantinidou, 2015).

In Thailand, previous studies have examined the attitudes of university students towards EMI. Choomthong (2014) found that Thai students had unsatisfactory English proficiency, and they are less proficient in English than other developing countries. Due to Thai students' limited exposure to English, it is difficult for them to master the English language. A study conducted by Hengsadeekul, Koul \& Kaewkuekool (2014) investigated the factors influencing students' attitudes towards EMI. The study revealed that the significance of the English language classroom learning environment, social support, and mastery and integrated goal orientations as major motivational factors influence Thai students' preference for EMI programs for their graduate studies and minimize their language anxiety. 
Successful implementation of EMI courses and programs at the higher education level relies heavily on the perceptions of those involved in the implementation process, particularly students. Students' attitudes are considered a crucial factor for the effectiveness of EMI (Mehisto \& Asser, 2007). Such perceptions can influence their learning behaviors and achievement (Koul \& Kaewkuekool, 2010). In addition, discovering students' perceptions about EMI will help both students and teachers in the learning and teaching process. One of the significant predictors of success in EMI is English language proficiency. Several authors have noted that good command of English of students is fundamental for successful EMI implementation (Dearden, 2015; Galloway et al., 2017; Simpson, 2019). Similarly, Rose, Curle, Aizawa, and Thompson (2019) found that students saw success in EMI as maintaining the quality of content learning with successful lecture comprehension, improving English language knowledge, and enhancing long-term career success.

Even though the research into EMI is growing, little attention has been paid to those EFL learners who are undertaking academic studies in EMI. Most studies in the field of EMI have only focused on policymakers and teachers. In addition, the factors influencing students' attitudes towards EMI have remained unclear. This indicates an urgent need to understand the various perceptions of EMI that exist among students. Understanding the students' perspectives would contribute to the effectiveness of EMI.

In contexts where English is not the first language nor the medium of communication, EMI is adapted to suit the varying aims of the programs offered by universities. Some programs used EMI to teach all content courses. Others have opted to teach some parts of a content course in English, for example, 30 percent for English instruction and 70 percent for Thai. It is interesting to know the attitude differences of students with varying background variables, for example, full or partial EMI program.

This study, therefore, focuses on students' perceptions concerning EMI, which is an essential aspect of ongoing changes in higher education. It also investigates the relevant factors which influence their perceptions of EMI. The current research was conducted in a Thai context where the EMI courses and programs at higher education institutions are new. It addressed the following research questions: (1) Are there significant differences in students' EMI attitudes based on their differing background variables? (2) What are the factors that affect students' attitudes toward EMI?

\section{LITERATURE REVIEW}

\section{A. English as a Medium of Instruction}

In recent years, there has been an increasing amount of literature on EMI to meet the demand for internationalization and globalization. According to the definition of EMI by Macaro, Curle, Pun, An, and Dearden (2018), it refers to "the use of the English language to teach academic subjects (other than English itself) in countries or jurisdictions where the first language of the majority of the population is not English" (p. 37).

EMI has become a prevalent approach to teaching content courses at the higher education level in non-English speaking countries (Byun et al., 2011; Huang, 2013; Dearden, 2015; Fenton-Smith, Humphries \& Walkinshaw, 2017). With the promotion of EMI in regional universities in Southeast Asia, the most significant number of EMI courses and programs are offered by local universities in Thailand (Kirkpatrick, 2017). In addition, many universities provide EMI to all programs or some departments with some sort of disciplinary distinction, for instance, science and engineering. In contrast, some programs prefer to have bilingual instruction, partly in English and in L1.

Swain and Johnson (1997) draw our attention to distinctive categories of EMI often observed in all education levels. It consists of full and partial EMI. Full EMI is a form of education in which the native language is not allowed to use. English is, therefore, the only medium of communication in class, while Thai (L1), for example, is not permitted. On the other hand, partial EMI refers to a bilingual program in which less than $50 \%$ of the curriculum is taught in English. Considering the use of English as the partial medium of instruction in specific academic disciplines, it has been suggested that bilingual communication such as English and Thai should be adopted (Poon, 2013). Unlike the textbooks, materials, and examinations in English, translating concepts in lectures into Thai is allowed (Poon, 2013). Having both full and partial models, EMI in Thailand's context aims to enhance their international outlook and generate a workforce with high English proficiency for the nation (Thitthongkam \& Walsh, 2011).

\section{B. Students' Attitudes of English as a Medium of Instruction: A Review of Studies}

A relatively small body of literature is mainly concerned with students' attitudes towards EMI, compared to those of policymakers and teachers. As a result, students' perceptions are not well understood. Researching students' perceptions of the EMI in their academic studies is crucial since their views can influence learning behaviors and achievement. This is also related to the interest in English medium learning. Identifying students' perceptions toward EMI can reduce problems for students attempting to learn content in English and help them learn more effectively. This will provide more opportunities for students to develop both their English language ability and content knowledge (Pun \& Thomas, 2020). Exploring students' attitudes about EMI will help both students and teachers in the learning and teaching process. Thus, their concerns should be taken seriously. 
Factors influencing students' attitudes towards EMI have been explored in several studies concerning the perceived benefits of EMI, challenges of EMI, and perceived needs. However, little has been known about how students perceive EMI in the Thai context, specifically, among engineering and nursing students.

\section{Perceived Benefits of EMI}

To date, several studies have shown that there are many reasons why EMI has become dominant in higher education levels. As Tamtam, Gallagher, Olabi, and Naher (2012) states bilingualism is the root of 'career and studying opportunities' (p. 1423). Yen and Thong (2019) have drawn three significant perceived benefits of EMI: more exposure to English and more chances to acquire it, the increased employability chances of students, and resource availability.

Considering the English language improvement, Galloway (2017) believes that EMI enhances students' English proficiency. Since EMI provides the opportunity to learn the English language through the medium of instruction in content subjects, it can help students improve their English proficiency. Likewise, in the study of Rose and Galloway (2019: 195), many universities revealed the language learning benefits of EMI as an 'expectation that English language proficiency will develop in tandem with subject discipline knowledge'. Therefore, language skills are seen as an improvement of a 'by-product' of studying content in English (Taguchi, 2014, p. 89). The considerable progress in all skills: listening, speaking, reading, and writing skills of students in the Arabian Gulf was also found in a study by Belhiah and Elhami (2015).

Another significant perceived benefit of EMI is the enhancement of career goals. Being a proficient English language user supports students' employment prospects in the future. With an increasing number of foreign companies located worldwide, students' career prospects and employability in the labor market are available for students to acquire (Yen \& Thong, 2019).

Regarding resource availability, EMI provides students with access to textbooks and other related materials not available in their native language. Most textbooks and materials are usually published in English, especially in the scientific field. Therefore, students are required to be proficient in English to access these resources (Alhamami, 2015; Yen \& Thong, 2019).

Furthermore, motivation is one of the key factors affecting student performance and learning. Students' interest in the content and their perceived relevance and benefits of the English language can influence motivation (Hengsadeekul, Koul \& Kaewkuekool, 2014). When students perceive some benefits to their learning, they will likely be more motivated to perform the task well, enhancing their knowledge and attaining their goals.

\section{Challenges of EMI}

Though various perceived benefits are presented, a considerable amount of literature has been published on the challenges of EMI. These studies point out several concerns about English language proficiency that students have expressed in EMI programs (Macaro, Curle, Pun, An, \& Dearden, 2018; Chen, Han, \& Wright, 2020). Previous studies have shown that EFL students in EMI classrooms encounter many linguistic challenges such as difficulty in comprehending lectures, difficulty understanding textbooks and course materials, difficulty in taking part in classroom discussions, and requiring more time to complete a course. These challenges may have a negative impact on students' success in their learning.

Concerning the challenges related to the difficulties of the English language, one study by Hellekjær (2010) found that EFL students in EMI programs struggle to understand lecture content delivered in English. Chang (2010) also showed that limited vocabulary and slow reading speed lead to the inability to understand the learning content. Likewise, the English language level of difficulty used in the materials causes students to have a low level of reading comprehension (Le, 2015). In corresponding with the problem in comprehending textbooks and course materials, students have to use a dictionary to translate the meaning of unfamiliar words and terminology, which is timeconsuming. In addition, students with low English competence have difficulty expressing themselves, so they are unwilling to pose questions related to the discussion of the content taught (Ibrahim, 2001).

Many recent studies (e.g., Galloway, Kriukow, \& Numajiri, 2017) have shown that academic English proficiency influences students' performance in many ways in non-English speaking contexts. This includes acquiring subject knowledge, requiring longer to complete courses, increased drop-out rates, and issues related to communicating course content. As stated in the large-scale study in Korea, Kang and Park (2005) reported that English proficiency levels impact students' ability to understand lectures. In this study, they also found that low proficiency was related to a higher level of anxiety.

In the same vein, Hengsadeekul, Koul \& Kaewkuekool (2014) revealed that Thai students' perceptions of their linguistic abilities were negative due to their speaking anxiety, fear of negative evaluation, and fear of social comparison. It has been suggested that only confident English speakers were sufficiently motivated. Students with high levels of foreign language anxiety may impact their learning achievement and may exhibit avoidance behaviors such as missing class and postponing homework.

In an analysis of home and international students' variation, Kim, Tatar, and Choi (2014) found that international students had higher confidence in using English comparing with Korean as home students who perceived their level of English was insufficient to understand the content. Similarly, Chapple (2015) noted that the Japanese (home) students in 
his study struggled with EMI, whereas some of the international students felt their time was being wasted to accommodate the relatively low proficiency of the Japanese students.

The challenges reviewed here seem to suggest to further investigate EMI in a particular context where it is implemented. As the difficulty of the English language is one of the significant concerns in EMI implementation, additional support for language skills should be promoted.

\section{Perceived Needs}

More recent attention has focused on the needs analysis that should be adapted to specific EMI contexts that vary according to the context, university, and discipline (Ellison, Aráujo, Correia, \& Vieira, 2017). It includes the provision of additional support needed for students' language and academic skills (Bradford, 2013; Galloway et al., 2017; Galloway \& Ruegg, 2020; Ishikura, 2015; Kelo, Rogers, \& Rumbley, 2010; Lassegard, 2006).

Previous research claimed that students fail to achieve English competency mainly due to insufficient communication language approach and supportive environment where there is little opportunity to practice English daily. This also resulted in a lack of confidence in using English. Similarly, Thai students have a limited chance of using English and have not had many feelings of success in their learning experience. Hence, it is necessary to offer the students a supportive environment for improving English, where teachers and students can share a space to use English.

In a comparative study of EMI provision in China and Japan, Galloway et al. (2017) revealed that student attitudes towards academic and language support varied. Nevertheless, most students reported that EMI content lecturers need to help them with their language-related needs. Therefore, the EMI content classes should also be supplemented with English language support classes. Likewise, another study in Japan undertaken by Bradford (2013) suggests that students enrolled in EMI programs should have access to academic writing support.

In addition, Galloway and Ruegg (2020) highlight the needed support in both the language and academic skills classes for students in EMI programs. This can be either pre-sessional or in-sessional classes and self-access support services to help students dealing with language or academic skills problems. Therefore, the context- and subject-specific support that responds to the needs of students in a particular institution or department is needed.

Overall, the evidence reviewed here suggests a significant role in how students perceive EMI and what relevant factors affect their attitudes towards EMI. Identifying students' perceptions toward English medium can reduce problems that occurred with students during their learning process. However, several aspects of factors influencing EMI students' attitudes remain, which relatively little is known and context-dependent. Hence, this study highlights the need for understanding the closely associated factors influencing students' attitudes of EMI that can lead to their learning effectiveness.

\section{Methodology}

This study employed a quantitative approach in collecting and analyzing data collected from a survey questionnaire on EMI.

\section{A. Research Context}

The study was conducted in a top-ranked science and technology varsity in northeast Thailand. The university offers international (English language is used as the medium of instruction) and Thai (Thai language is used as the primary medium of instruction) undergraduate programs in science, information technology, management technology, agricultural technology, engineering, medicine, public health, and nursing. However, in Thai programs, the university encourages lecturers to teach content courses in both English and Thai. For example, in one of the nursing content courses, 30 to 50 percent is taught in English by a lecturer who studied abroad, while another lecturer in Thai teaches 50 to 70 percent.

In this study, two types of programs - full and partial were considered. Full EMI means that all courses are taught in English. The mechanical engineering undergraduate degree was selected as an international program and fitted the description of complete EMI. On the other hand, partial EMI refers to a program where two lecturers teach some content courses in English and Thai. The nursing program was chosen as it fits a partial EMI context.

\section{B. Participants of the study}

Convenience sampling was used. In total, 102 university students in engineering and nursing programs volunteered to participate in the study. Table 1 summarizes 11 background variables included: program of study, gender, nationality, year level, number of years studying English, medium of instruction in high school, CEFR level, and perceived proficiencies in speaking, reading, writing, and listening. 
TABLE 1

BACKGROUND VARIABLES AND FREQUENCIES

\begin{tabular}{|c|c|}
\hline Type of EMI program & Partial EMI $(n=37) ;$ Full EMI $(n=65)$ \\
\hline Gender & Male $(n=36) ;$ Female $(n=64) ;$ Prefer not to say $(n=2)$ \\
\hline Nationality & Thai $(n=80)$; Foreigners $(n=22)$ \\
\hline Year level & First year $(n=5) ;$ Second year $(n=42)$; Third year $(n=50)$; Fourth year $(n=5)$ \\
\hline Number of years studying English & $2-3$ years $(n=6) ; 4-6$ years $(n=25) ; 7-8$ years $(n=19) ;$ More than 8 years $(n=52)$ \\
\hline Medium of instruction in high school & English $(n=16)$; Thai $(n=86)$ \\
\hline CEFR level & $\mathrm{A} 1(n=14) ; \mathrm{A} 2(n=23) ; \mathrm{B} 1(n=27) ; \mathrm{B} 2(n=24) ; \mathrm{C} 1(n=10) ; \mathrm{C} 2(n=4)$ \\
\hline Perceived proficiency in speaking & Beginner $(n=34) ;$ Intermediate $(n=62)$; Advanced $(n=6)$ \\
\hline Perceived proficiency in reading & Beginner $(n=14) ;$ Intermediate $(n=72) ;$ Advanced $(n=10)$ \\
\hline Perceived proficiency in writing & Beginner $(n=37)$; Intermediate $(n=62)$; Advanced $(n=3)$ \\
\hline Perceived proficiency in listening & Beginner $(n=21) ;$ Intermediate $(n=71) ;$ Advanced $(n=10)$ \\
\hline
\end{tabular}

\section{Instrument}

The survey questionnaire was adopted from an online-based EMI questionnaire. The items and questions were revised accordingly to suit the current context of the study. It was written in both Thai and English to ensure the comprehensibility of questions among Thai and international students. It consisted of seven sections on demographic data, perceived benefits of their chosen program of study (10 items), perceived difficulties of EMI (8 items), perceived personal challenges ( 9 items), perceive supports needed (6 items), perceived English activities needed (4 items), and attitudes toward learning content in English (9 items). The 46 survey items (see Appendix) contained a 4-point Likert scale, namely "Strongly disagree", "Disagree", "Agree", and "Strongly Agree". The survey questionnaire was administered online via Google form.

To establish content validity, eight lecturers reviewed the questions. After modifications were made, it was pilot tested to establish its reliability. Cronbach's Alpha was used and was found at 0.81 , high reliability.

\section{Data Analysis}

To know the differences of attitudes based on the participants' background variables, t-test (to calculate differences between two means) and analysis of variance (to calculate differences of several means) were used.

To know the factors, exploratory factor analysis was conducted on the 46 items with oblique rotation (varimax). To measure sampling adequacy, the Kaiser-Meyer-Olkin was measured at .69 (indicating sufficient items for each factor). Bartlett's test of sphericity showed $<.001$, suggesting a substantial correlation in the data. Eight components had eigenvalues over 1 and explained 75.28 percent of the variance. Four items were deleted as the correlation coefficient was less than .40. Thus, eight components were retained and reported in the study.

\section{FINDINGS}

Two questions are sought in the present study. The first question was to find the differences in students' attitudes based on their background variables. The second question was to explore the factors that affect students' attitudes toward EMI.

\section{A. Are There Significant Differences in Students' Emi Attitudes Based on Their Differing Background Variables?}

The table 2 shows significant differences in the following background variables - the program of study in aspect 1; nationality in aspect 1; CEFR level in aspects, 2, 3, and 6; perceived proficiency in speaking in aspects 2 and 6; perceived proficiency in reading in aspects 2 and 3; perceived proficiency in writing in aspects 1,2, 3 and 6; and, perceived proficiency in listening in aspects $1,2,3$, and 6. 
TABLE 2

DIFFERENCES BASED ON BACKGROUND VARIABLES

\begin{tabular}{|c|c|c|c|c|c|c|}
\hline Background variable & $\begin{array}{c}\text { Aspect } 1 \\
\text { Perceived } \\
\text { benefits of their } \\
\text { program of } \\
\text { study }\end{array}$ & $\begin{array}{c}\text { Aspect } 2 \\
\text { Perceived } \\
\text { difficulties of EMI }\end{array}$ & $\begin{array}{l}\text { Aspect } 3 \\
\text { Perceived } \\
\text { personal } \\
\text { challenges }\end{array}$ & $\begin{array}{c}\text { Aspect } 4 \\
\text { Perceived } \\
\text { supports needed }\end{array}$ & $\begin{array}{c}\text { Aspect } 5 \\
\text { Perceived English } \\
\text { activities needed }\end{array}$ & $\begin{array}{c}\text { Aspect } 6 \\
\text { Attitudes } \\
\text { toward learning } \\
\text { content in } \\
\text { English }\end{array}$ \\
\hline Type of EMI program & $.000^{* * *}$ & - & - & - & - & - \\
\hline Gender & - & - & - & - & - & - \\
\hline Nationality & $.013 *$ & - & - & - & - & - \\
\hline Year level & - & - & - & - & - & - \\
\hline $\begin{array}{c}\text { No of years studying } \\
\text { English }\end{array}$ & - & - & - & - & - & - \\
\hline $\begin{array}{l}\text { Major lg of instruction } \\
\text { in high school }\end{array}$ & - & - & - & - & - & - \\
\hline CEFR level & - & $.000^{* * *}$ & $.003 * *$ & - & - & $.001 * *$ \\
\hline PP in speaking & - & $.000^{* * *}$ & - & - & - & $.002 * *$ \\
\hline $\mathrm{PP}$ in reading & - & $.000 * *$ & $.005 * *$ & - & - & - \\
\hline PP in writing & $.025 *$ & $.000 * *$ & $.045^{*}$ & - & - & $.001 * *$ \\
\hline PP in listening & $.041 *$ & $.000^{* * *}$ & $.009 * *$ & - & - & $.020^{*}$ \\
\hline
\end{tabular}

$*$ indicates <.05; ** indicates <.001

\section{B. What Are the Factors that Affect Students' Attitudes toward EMI?}

The factors (see Fig. 1) affecting the attitudes of engineering and nursing students in a Thai university are (1) difficulties of the English language having ten items, (2) availability of resources and opportunities with six items, (3) personal goals in life covering seven items, (4) limitations of time with six items, (5) providing activities to improve English language proficiency having four items, (6) enhancement of career goals covering three items, (7) supports needed with four items, and (8)motivation and intercultural ability having two items.

The first factor, "Difficulties of the English language," covers difficulties in learning and understanding the content in English, difficulties in speaking, reading, comprehending, writing, and thinking in English, difficulty in knowing the cultural component of the lesson, and the difficulty of the learning process when studying in English. The second factor, "Availability of resources and opportunities," involves preparing more resources in learning both content and language, making resources more interactive in using English, creating an environment where students are fully supported, and providing more opportunities for student-teacher interaction well as peer activities. Next, "Personal goals in life" covers developing cultural awareness, becoming a multicultural person, studying abroad, daily use of English, making friends from other countries, improving their English skills, and enhancing knowledge in a subject taught in English. The fourth factor, "Limitations of time when studying EMI content courses," is based on slow progress when studying the content in English, consumes a lot of time to learn content in English, a lot of time spent in looking for resources in English, difficulty in expressing thoughts when studying content in English, and learning to develop cultural sensitivity when studying content in English. The fifth factor, "Providing activities to improve English language proficiency," focuses on the activities which could develop speaking, reading, writing, and listening skills. Next, "Enhancement of career goals" covers enhancement of future employment opportunities and value of the degree, and becoming more self-confident in using English. The seventh factor, "Supports needed," underscores the lack of support to enhance English ability, lack of support to understand the difficult content, lack of environment to practice English, and unclear instructions in English. Finally, the last factor, "Motivation and intercultural ability," is based on lack of motivation for learning and lack of intercultural ability.

\section{Discussion, IMPLICATIONS, AND CONCLUSIONS}

Findings from the survey questionnaire revealed several background variables and aspects that differentiate students' EMI attitudes. Concerning the students' perceived benefits of their program of study, significant differences were found based on the type of EMI program and nationality. Such result is not surprising as engineering and nursing students are fully aware of the nature of their program of study - the engineering group are expected to be exposed to English daily, become proficient in English, their EMI program enhances future employment and the value of their degree, and increase self-confidence in using English. Meanwhile, the significant difference between Thais and non-Thais could be attributed to the latter group's academic reputation. In the context of this study, international students are admitted based on their excellent academic records and high English language proficiency as they are offered full scholarships, including free housing and monthly allowance. Also, like Kim, Tatar, and Choi (2014) reported, international students have higher self-confidence in using English. 


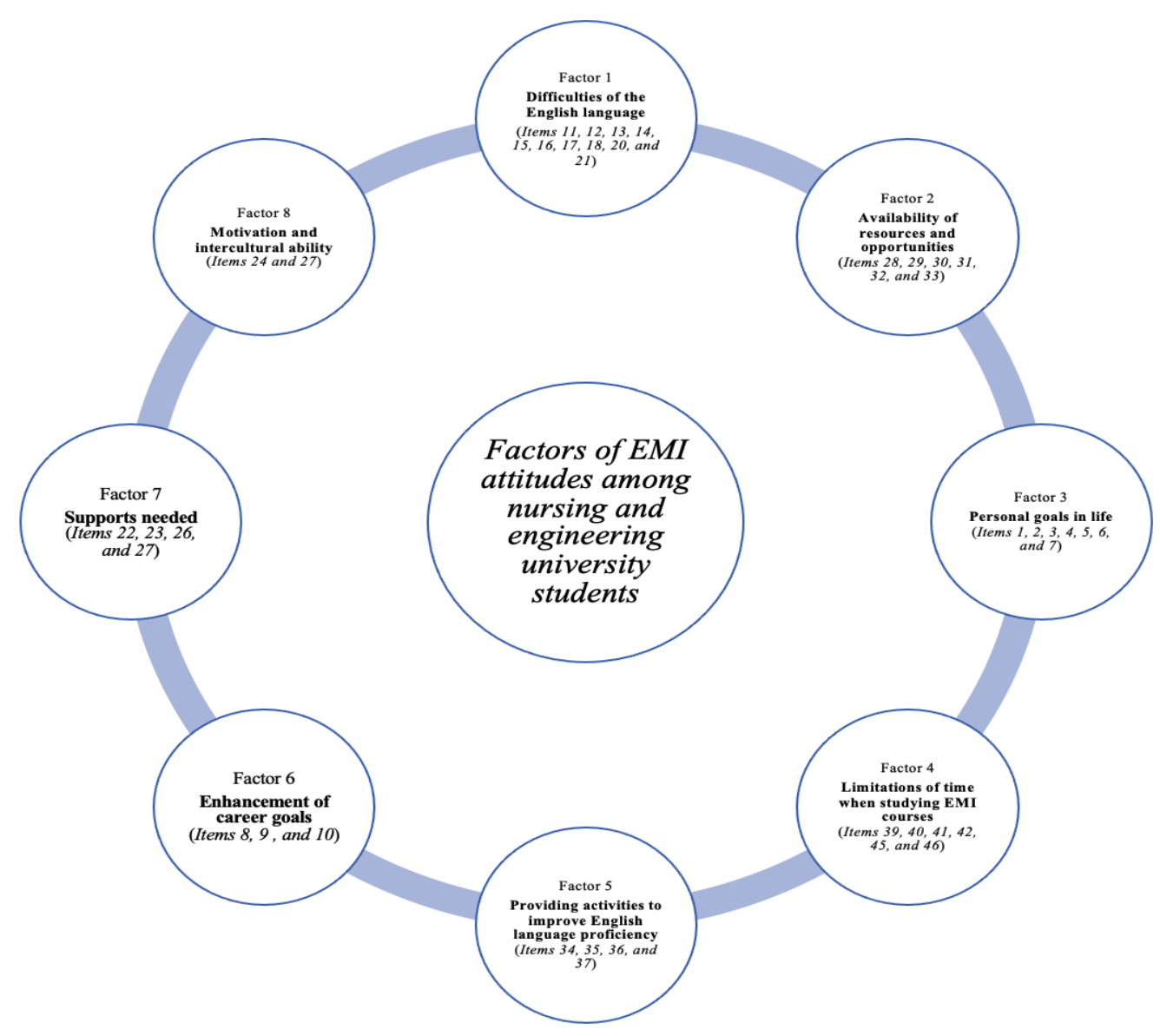

Figure 1. Factors of EMI Attitudes among Thai University Students

Further findings from the survey questionnaire have also shown that English language proficiency (see CEFR level and perceived proficiencies) impacts the students' perceived difficulties of EMI, perceived personal challenges, and attitudes toward content in English. Similar to previous literature (see Galloway \& Ruegg, 2020; Galloway, Kriukow \& Numajiri, 2017; Hengsadeekul, Koul \& Kaewkuekool, 2014; Macaro, Curle, Pun, An, \& Dearden, 2018; Chen, Han, \& Wright, 2020), it appears that macro and micro English language skills remain a challenge in EMI-driven, partial or full, programs in Thai university context. Also, factor analysis affirmed such findings (see Factor 1, Difficulties of the English language). Perhaps, the student's personal goals in life (Factor 3) and enhancement of career goals (Factor 6) are keeping the students on track despite language challenges and lack of motivation (see Factor 8).

The other factors elicited such as availability of resources and opportunities (factor 2), limitations of time when studying EMI content courses (factor 4), providing activities to improve English language proficiency (factor 5), and supports needed (factor 7) provide evidence that students enrolled in Thai EMI programs need supports to overcome linguistic challenges. Like in other EFL contexts (see Bradford, 2013; Galloway, Kriukow \& Numajiri, 2017), language-related supports provided include providing resources, learning space, and activities.

Some teaching implications were drawn from the results of the study. Since the limitation of time when studying EMI courses is one of the factors affecting students' attitudes, teachers may provide more time for students to process the content. Simply asking students in class if more time is needed to accomplish the task could be of great help. Doing this could guide teachers to decide whether a task should be done in pairs, groups, or as homework. With sufficient time allotted for the students to find resources or express their thoughts, student outputs may be better. In partial or full EMI classrooms, teachers should find ways to identify students who struggle with the lesson and provide necessary assistance - in class or out of class, on-site or online. For instance, teachers may allow recording of the lecture for review purposes. If teachers are not comfortable with the recordings, they may share annotated PowerPoints or notes for the students.

Providing continuous support to improve student's language proficiency is highly recommended. Faculties and universities may devise appropriate plans to help students based on the factors derived from the present study. For example, continuous appraisal of students' perceived challenges may help create differentiated language programs suitable for each individual or group's needs. In addition, universities should be clear on any EMI-related policy, so students know what is expected regarding their program of study. For example, it would be unfair for students with low English language proficiency and enrolled in a Thai program to study in partial EMI content courses. While it could be 
true that partial EMI programs may help students become better in L2, it may lead to negative attitudes, which affect other variables, for example, motivation in learning.

The students in the present study expressed concern about the difficulties in learning both content and language. It also revealed background variables that affect the attitude of students toward EMI. Further, findings offer insights on the aspects of EMI programs that should be considered or reconsidered based on the factors elicited from participants in this study.

APPENDIX

\begin{tabular}{|c|c|c|}
\hline \multirow[t]{2}{*}{ Perceived benefits of their program of study } & Nursing & Engineering \\
\hline & $M, \mathrm{SD}$ & $M, \mathrm{SD}$ \\
\hline 1. To improve my English skills & 2.64, 0.94, Agree & $3.55,0.68$, Strongly agree \\
\hline 2. To enhance my knowledge in a subject taught in English & 2.81, 0.87, Agree & $3.55,0.61$, Strongly agree \\
\hline 3. To study abroad (e.g., exchange program). & $2.75,0.89$, Agree & $3.33,0.75$, Strongly agree \\
\hline 4. To use English on a daily basis & $3.05,0.84$, Agree & $3.40,0.68$, Strongly agree \\
\hline 5. To make friends from other countries. & 2.78, 0.97, Agree & $3.01,0.81$, Agree \\
\hline 6. To develop cultural awareness & 2.70, 0.77, Agree & 2.83, 0.80, Agree \\
\hline 7. To become a multicultural person & $2.97,0.79$, Agree & $3.04,0.79$, Agree \\
\hline 8. To enhance my future employment opportunities & $3.64,0.58$, Strongly agree & $3.73,0.53$, Strongly agree \\
\hline 9. To enhance the value of my degree & $3.51,0.60$, Strongly agree & $3.58,0.65$, Strongly agree \\
\hline 10. To increase my self-confidence in using English & $3.32,0.74$, Strongly agree & $3.55,0.66$, Strongly agree \\
\hline \multicolumn{3}{|c|}{ Perceived difficulties of EMI } \\
\hline 11. The content is difficult to learn in English & $2.81, .070$, Agree & 2.44, 0.79, Disagree \\
\hline 12. It is difficult to speak English & $2.70,0.77$, Agree & $1.98,0.64$, Disagree \\
\hline 13. It is difficult to read texts in English & $2.56,0.64$, Agree & $1.95,0.67$, Disagree \\
\hline 14. It is difficult to comprehend spoken English & $2.72,0.76$, Agree & $2.06,0.70$, Disagree \\
\hline 15. It is difficult to write in English & $2.89,0.87$, Agree & $2.21,0.69$, Disagree \\
\hline 16. It is difficult to think in English & $2.94,0.74$, Agree & $2.18,0.70$, Disagree \\
\hline 17. The learning process when studying in English is difficult & $2.75,0.79$, Agree & 2.07, 0.73, Disagree \\
\hline 18. It is difficult to know the cultural components of the lesson & $2.64,0.85$, Agree & $2.26,0.73$, Disagree \\
\hline \multicolumn{3}{|c|}{ Perceived personal challenges } \\
\hline 19. Low level of my English proficiency & $2.72,0.80$, Agree & $2.47,0.70$, Disagree \\
\hline 20. The difficulty of the content & $2.97,0.68$, Agree & $2.78,0.78$, Agree \\
\hline 21. My difficulty with understanding the content in English & $2.97,0.64$, Agree & $2.55,0.68$, Agree \\
\hline 22. The program's lack of support to enhance my English ability & $2.48,0.83$, Disagree & $2.66,0.81$, Agree \\
\hline $\begin{array}{l}\text { 23. The program's lack of supports to understand the difficult } \\
\text { content (e.g., supplementary resources) }\end{array}$ & $2.48,0.70$, Disagree & $2.56,0.80$, Agree \\
\hline 24. My lack of motivation for learning & $2.32,0.78$, Disagree & $2.44,0.77$, Disagree \\
\hline 25. My lack of intercultural ability & $2.27,0.69$, Disagree & $1.13,0.68$, Strongly disagree \\
\hline 26. The lack of environment to practice English & $2.83,0.86$, Agree & $2.80,0.85$, Agree \\
\hline 27. The instructions in English are unclear to me & $2.54,0.86$, Agree & $2.35,0.71$, Disagree \\
\hline \multicolumn{3}{|c|}{ Perceived supports needed } \\
\hline 28. Prepare more resources for studying content in English & $3.18,0.65$, Agree & $3.24,0.58$, Agree \\
\hline 29. Prepare more resources for studying English language & $3.18,0.65$, Agree & $3.21,0.57$, Agree \\
\hline 30. Make the available resources more interactive in using English & $3.08,0.72$, Agree & $3.29,0.60$, Strongly agree \\
\hline 31. Create the environment where students are supported & $3.24,0.59$, Agree & $3.30,0.65$, Strongly agree \\
\hline 32. Provide more opportunities for student-teacher interaction & $3.08,0.72$, Agree & $3.23,0.67$, Agree \\
\hline 33. Provide more opportunities for peer activities & $3.16,0.68$, Agree & $3.30,0.68$, Strongly agree \\
\hline \multicolumn{3}{|c|}{ Perceived activities to develop English skills } \\
\hline 34. Activities which develop speaking skills & $3.37,0.68$, Strongly agree & $3.52,0.53$, Strongly agree \\
\hline 35. Activities which develop writing skills & $3.13,0.82$, Agree & $3.38,0.57$, Strongly agree \\
\hline 36. Activities which develop writing skills & $3.24,0.64$, Agree & $3.15,0.71$, Agree \\
\hline 37. Activities which develop reading skills & $3.29,0.66$, Strongly agree & $3.47,0.58$, Strongly agree \\
\hline \multicolumn{3}{|c|}{ Attitudes toward learning content in English } \\
\hline $\begin{array}{l}\text { 38. My English skills have improved since I have started studying } \\
\text { in this course/program }\end{array}$ & $2.70,0.66$, Agree & $3.10,0.58$, Agree \\
\hline $\begin{array}{l}\text { 39. My progress in the content subject would be faster if studying it } \\
\text { in my native language (e.g., Thai) }\end{array}$ & $3.00,0.84$, Agree & $2.83,0.85$, Agree \\
\hline 40. It's not time consuming* & $2.29,0.84$, Disagree & $2.49,0.77$, Disagree \\
\hline $\begin{array}{l}\text { 41. I spend less time looking for the resources for learning content } \\
\text { in English* }\end{array}$ & $2.21,0.85$, Disagree & $2.40,0.72$, Disagree \\
\hline $\begin{array}{l}\text { 42. To understand content studied in English I often use resources } \\
\text { in my native one (e.g., Thai) }\end{array}$ & 2.94, 0.88, Agree & $2.50,0.85$, Disagree \\
\hline $\begin{array}{l}\text { 43. The resources I use develop my knowledge of content but do } \\
\text { not help me with the language }\end{array}$ & $2.75,0.86$, Agree & 2.53, 0.70, Agree \\
\hline 44. It's not difficult to stay motivated* & $2.51,0.76$, Agree & 2.49, 0.97, Disagree \\
\hline $\begin{array}{l}\text { 45. It's easy for me to effectively express my ideas when studying } \\
\text { the content in English* }\end{array}$ & $2.00,0.81$, Disagree & $2.29,0.78$, Agree \\
\hline $\begin{array}{l}\text { 46. When studying content in English I have learned to develop a } \\
\text { cultural sensitivity }\end{array}$ & 2.94, 0.74, Agree & 2.87, 0.73, Agree \\
\hline
\end{tabular}

*Item was reverse-coded. 


\section{REFERENCES}

[1] Alhamami, M. (2015). Teaching science subjects in Arabic: Arab university scientists' perspectives. Language Learning in Higher Education, 5(1), 105-123.

[2] Andrade, M. S. (2006). International students in English-speaking universities: Adjustment factors. Journal of Research in International Education, 5(2), 131-154.

[3] Belhiah, H. \& Elhami, M. (2015). English as a medium of instruction in the Gulf: When students and teachers speak. Language Policy 14(1), 3-23.

[4] Bradford, A. (2013). English-medium degree programs in Japanese universities: Learning from the European experience. Asian Education and Development Studies, 2(3), 225-240.

[5] Byun, K., Chu, H., Kim, M., Park, I., Kim, S., \& Jung, J. (2011). English medium teaching in Korean higher education: Policy debates and reality. Higher Education, 62(4), 431-449.

[6] Chang, Y. Y. (2010). English-medium instruction for subject courses in tertiary education: Reactions from Taiwanese undergraduate students. Taiwan International ESP Journal, 2(1), 55-84.

[7] Chapple, J. (2015). Teaching in English is not necessarily the teaching of English. International Education Studies, 8(3), 1-13.

[8] Chen, H., Han, J., \& Wright, D. (2020). An investigation of lecturers' teaching through English medium of instruction-A case of higher education in China. Sustainability, 12(10), 4046.

[9] Choomthong, D. (2014). Preparing Thai students' English for the ASEAN Economic Community: Some pedagogical implications and trends. Language Education and Acquisition Research Network (LEARN) Journal, 7(1), 45-57.

[10] Dearden, J. (2015). English as a medium of instruction - a growing global phenomenon. London: British Council.

[11] Doungphummes, N., \& Chandransu, N. (2016). Approaches to Enhance English Communicative Competence of A Synthetic Account of Targeted Research Series in English Learning Promotion. Journal of Language and Culture, 35(2), 77-96.

[12] Ellison, M., Aráujo, S., Correia, M., \& Vieira, F. (2017). Teachers' perceptions of need in EAP and ICLHE contexts. In Valcke, J., \& Wilkinson, R., Integrating Content and Language in Higher Education: Perspectives on Professional Practice (pp. 59-76). Peter Lang Publishing Group.

[13] Fenton-Smith, B., Humphries, P. \& Walkinshaw, I. (2017). English medium instruction in higher education in Asia Pacific: From policy to pedagogy. Dordrecht: Springer.

[14] Galloway, N., \& Ruegg, R. (2020). The provision of student support on English Medium Instruction programmes in Japan and China. Journal of English for Academic Purposes, 45, 100846.

[15] Galloway, N., Kriukow, J., \& Numajiri, T. (2017). Internationalisation, higher education and the growing demand for English: An investigation into the English medium of instruction (EMI) movement in China and Japan.

[16] Galloway, N. (2017). How effective is English as a medium of instruction (EMI)? Retrieved March 9, 2020 from https://www.britishcouncil.org/voices-magazine/how-effective english-medium-instruction-em

[17] Hellekjær, G. O. (2010). Lecture comprehension in English-medium higher education. Hermes-Journal of Language and Communication Studies, 45, 11-34.

[18] Hengsadeekul, C., Koul, R. \& Kaewkuekool, S. (2014). Motivational orientation and preference for English-medium programs in Thailand. International Journal of Educational Research, 66, 35-44.

[19] Hu, G., \& Lei, J. (2014). English-medium instruction in Chinese higher education: A case study. Higher Education, 67(5), 551567.

[20] Huang, Y. P. (2013). Design and implementation of English-medium courses in higher education in Taiwan: A qualitative case study. English Teaching \& Learning, 36(1), 1-51.

[21] Ibrahim, J. (2001). The implementation of EMI (English medium instruction) in Indonesian universities: Its opportunities, its threats, its problems, and its possible solutions. $k @ t a, 3(2), 121-138$.

[22] Ishikura, Y. (2015). Realizing internationalization at home through English-medium courses at a Japanese University: Strategies to maximize student learning. Higher Learning Research Communications, 5(1), 11-28.

[23] Kang, S. \& H. Park (2005). English as the medium of instruction in Korean Engineering education. Korean Journal of Applied Linguistics, 21(1), 155-174.

[24] Kim, J., Tatar, B. \& Choi, J. (2014). Emerging culture of English-medium instruction in Korea: Experiences of Korean and international students. Language and Intercultural Communication, 14(4), 441- 459.

[25] Kirkgöz, Y. (2005). Motivation and student perception of studying in an English-medium university. Journal of Language and Linguistic Studies, 1(1), 101-123.

[26] Kirkpatrick, A. (2017). The languages of higher education in East and Southeast Asia: Will EMI lead to Englishization? In B. Fenton-Smith, P. Humphreys, \& I. Walkinshaw (Eds.), English Medium Instruction in Higher Education in Asia Pacific. Multilingual Education, vol 21. Springer, Cham.

[27] Kelo, M., Rogers, T., \& Rumbley, L. E. (2010). International student support in European higher education: Needs, solutions, and challenges. Lemmens Medien.

[28] Koul, R., \& Kaewkuekool, S. (2010). English as a medium of instruction in Thai universities: A review of literature. In selected topics in education and education technology: Proceedings from the 9th WSEAS International Conference on Education and Educational Technology (pp. 89-94).

[29] Lassegard, J. P. (2006). International student quality and Japanese higher education reform. Journal of Studies in International Education, 10(2), 119-140.

[30] Le, T. D. L. (2015). Content lecturers' and students' challenges in EMI classrooms: A case study at a university in the Mekong Delta. Unpublished Master's thesis. Can Tho University.

[31] Luanganggoon, N. (2020). Content and Language Integrated Learning (CLIL) teaching practices in Thailand Higher Education. The Asian ESP Journal, 16(4), 233-258.

[32] Macaro, E., Curle, S., Pun, J., An, J., \& Dearden, J. (2018). A systematic review of English medium instruction in higher education. Language Teaching, 51(1), 36-76. 
[33] Mehisto, P., \& Asser, H. (2007). Stakeholder perspectives: CLIL programme management in Estonia. International Journal of Bilingual Education and Bilingualism, 10(5), 683-701.

[34] Phuong, Y. H., \& Nguyen, T. T. (2019). Students' Perceptions towards the Benefits and Drawbacks of EMI Classes. English Language Teaching, 12(5), 88-100.

[35] Poon, J. (2013). Blended learning: An institutional approach for enhancing students' learning experiences. Journal of online learning and teaching, 9(2), 271-288.

[36] Pun, J. K., \& Thomas, N. (2020). English medium instruction: teachers' challenges and coping strategies. ELT Journal, 74(3), 247-257.

[37] Rose, H. \& Galloway, N. (2019). Global Englishes for Language Teaching. Cambridge: Cambridge University Press.

[38] Studer, P., \& Konstantinidou, L. (2015). Language attitudes and language proficiency of undergraduate students in Englishmedium instruction. Revue Tranel (Travaux neuchâtelois de linguistique), 3, 215-231.

[39] Swain, M., \& Johnson, R. K. (1997). Immersion education. In W. R. K. Johnson, \& M. Swain (Eds.) A Category Within Bilingual Education (pp. 1-18). Immersion Education: International Perspectives. Cambridge: CUP.

[40] Taguchi, N. (2014). English-medium education in the global society. International Review of Applied Linguistics, 52(2), 89-98.

[41] Tamtam, A. G., Gallagher, F., Olabi, A. G., \& Naher, S. (2012). A comparative study of the implementation of EMI in Europe, Asia and Africa. Procedia-Social and Behavioral Sciences, 47, 1417-1425.

[42] Thitthongkam, T., Walsh, J., \& Bunchapattanasakda, C. (2011). The roles of foreign language in business administration. Journal of Management research, 3(1), 1-15.

[43] Thompson, G., Aizawa, I., Curle, S., \& Rose, H. (2019). Exploring the role of self-efficacy beliefs and learner success in English medium instruction. International Journal of Bilingual Education and Bilingualism, O(0), 1-14.

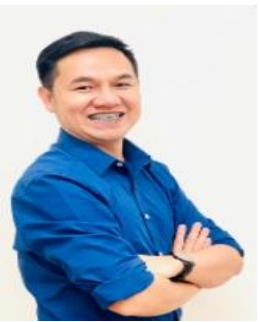

Jeffrey D. Wilang earned his bachelor's degree in Political Science from the University of the Cordilleras (UC) in the Philippines, his master's degree in Teaching English as an International Language from the Faculty of Liberal Arts, Prince of Songkla University (PSU), Hat Yai Campus in Thailand, and his Ph.D. in Applied Linguistics from the School of Liberal Arts, King Mongkut's University of Technology Thonburi (KMUTT), Thailand.

$\mathrm{He}$ is an assistant professor at the School of Foreign Languages, Institute of Social Technology, Suranaree University of Technology, Nakhon Ratchasima, Thailand. His research interests are psycholinguistics and English as a lingua franca.

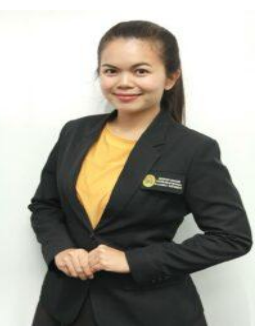

Supasinee Nupong is a Ph.D. student in English Language Studies at the School of Foreign Languages, Suranaree University of Technology in Thailand. She earned an M.A. in English as an International Language from Chulalongkorn University, and a B.A. in Business English from Khon Kaen University.

She is a lecturer in the School of Business English, Faculty of Humanities and Social Sciences, Nakhon Ratchasima Rajabhat University, Nakhon Ratchasima, Thailand. Her research interests are English teaching methodology, English for Specific Purposes, and English as a Medium of Instruction. 